\title{
Comparisons of Population Demography of Microtus ochrogaster and M. pennsylvanicus
}

\author{
Lowell L. GETZ, Louis VERNER, F. Russell COLE, \\ Joyce E. HOFMANN \& Diana E. AVALOS
}

\begin{abstract}
Getz L. L., Verner L., Cole F. R., Hofmann J. E. \& Avalos D. E., 1979: Comparisons of population demography of Microtus ochrogaster and M. pennsylvanicus. Acta theriol., 24, 24: 319-349 [With 6 Tables, 8 Figs. \& 1 Appendix].

Demography of two population cycles of Microtus ochrogaster and one of $M$. pennsylvanicus were compared in alfalfa, bluegrass and tall grass prairie habitats in east-central Illinois, 1972-1976. Peak densities of $M$. ochrogaster were greatest in alfalfa (240 and $110 / \mathrm{ha})$, lowest in prairie (37 and 12) and intermediate in bluegrass (1.25 and 60); peak densities of $M$. pennsylvanicus were: bluegrass, 49/ha; prairie, 31 ; alfalfa, 11. Length of the breeding season, as established by food availability, appeared responsible for the amplitude of fluctuation of $M$. ochrogaster populations, but did not drive the population cycle. Food availability did not influence amplitude of fluctuation or the population cycle of $M$. pennsylvanicus. Reproduction and survival were greater during the increase than during the decline phases in $M$. ochrogaster. There were no phase differences in reproduction and survival of $M$. pennsylvanicus. There was a negative correlation between reproduction and population density in $M$. ochrogaster, but not in $M$. pennsylvanicus. Changes in reproduction appeared to be a major factor responsible for initiating a $M$. ochrogaster population decline; increased juvenile mortality was of secondary importance. Increased juvenile mortality appeared to be a major factor in the population decline of $M$. pennsylvanıcus.

[iDept. Ecol., Ethol. and Evolution, Univ. Illinois, Urbana, Illinois 61801 (LLG, LV, DEA); Dept. Biol., Colby College, Waterville, Maine 04901 (FRC); Dept. Biol., California State Univ., Fresno, California $93740(\mathrm{JEH})]$.
\end{abstract}

\section{INTRODUCTION}

Among the microtine rodents are many species that undergo marked periodic fluctuation (»cycles«) in abundance. Although the timing and amplitude of such cycles vary temporally and geographically, identifiable peak densities generally occur at $2-5$ year intervals ( $\mathrm{K}$ r e b s \& M y e rs, 1974). Krebs (1964) and $\mathrm{Krebs} \&$ M yers (1974) have reviewed various hypotheses on the causality of microtine populations. However, no consensus has yet emerged concerning the relative significance of each of these, or other factors. 
Knowledge of demographic changes that occur during population cycles are essential for an analysis of factors generating population cycles. Data concerning the relationships between reproduction, survival, sex and age structure, and physiological condition of the animals and phase of the population cycle, population density, season, and food availability are required to design manipulative studies of the effects of specific factors.

During the course of a long-range integrated study of microtine rodent population fluctuations, we have obtained considerable demographic data pertaining to the prairie vole, Microtus ochrogaster, and the meadow vole, $M$. pennsylvanicus, in east-central Illinois. The meadow vole has been the subject of numerous demographic studies ( $\mathrm{H}$ a m il t o n, 1937; Getz, 1960; Golley, 1961; Krebs et al., 1969; Christian, 1971a; Birney et al., 1976), while detailed studies of prairie vole populations have been conducted in eastern Kansas (M a r t in, 1956, Fit c h, 1957; G a in es \& R ose, 1976), southern Indiana (K rebs et al., 1969; Gaines \& Krebs, 1971) and Nebraska (M e serve. 1971). Our data extend these observations and provide several compa risons not available in the above studies (including interspecific respon ses to the same factors).

This paper presents demographic data from March 1972-December 1976. During this period $M$. ochrogaster completed two cycles an 1 $M$. pennsylvanicus one cycle; neither species has undergone an increase phase as of March 1979.

\section{STUDY AREAS}

Populations of each of the two voles were studied in three habitat types (alfalfa. bluegrass, and restored tall grass prairie) located in the University of Illinois Biological Research Area and Trelease Prairie, $10 \mathrm{~km}$ northeast of Urbana, Illinois.

The alfalfa study area (1.4 ha) was released from domestic grazing in late autumn 1971. Vegetative growth started in early April 1972, producing a dense cover $0.5 \mathrm{~m}$ high by early May; at least $75 \%$ of the vegetation was alfalfa (Medicago sativa). By September 1972 numerous species of forbs and grasses had become abundant in the study area; the most common species present at that time (as determined by percent coverage along six $50-\mathrm{m}$ transects spaced equidistantly within the area) included: alfalfa (38\%); brome grass, Bromus spp. $(26 \%)$; Canada thistle, Cirsium arvense (12\%); dandelion, Taraxacum officinale (8\%); aster, Aster spp. (5\%); goldenrod, Solidago spp. (3\%); and clovers, Trifolium pratense and T. repens $(3 \%)$.

The alfalfa area underwent succession during the course of the study; alfalta plants decreased in abundance. By autumn 1976 other forbs and grasses dominated the area: bluegrass, Poa pratensis $(22 \%)$; alfalfa $(18 \%)$; goldenrod $(14 \%)$; timothy, Phleum pratense $(9 \%)$; bromegrass $(8 \%)$; clovers $(6 \%)$; dandelion $(6 \%)$; plantain, Plantago spp. (5\%); and 22 other species with frequencies of less than $1 \%$. Due :0 the dominance of forbs, this habitat contained very poor cover during the winter 
in comparison to the bluegrass and prairie areas, both of which had dense winter cover.

The bluegrass field ( 2 ha) was released from domestic grazing in June 1971; by August there was a dense cover of bluegrass over the entire field. Vegetation in the bluegrass area remained relatively constant throughout the study: bluegrass $(70 \%)$; dandelion (14\%); wild parsnip, Pastinaca sativa $(4 \%)$ : and goatsbeard, Tragopogon spp. (3\%); approximately 20 other species had frequencies of less than $1 \%$

The tall grass prairie ( $2 \mathrm{ha}$ ) was established in 1944 and has been burned at approximately 3-year intervals to maintain prairie grasses. The prairie was burned in late April 1971 and 1974. The relative abundance of plants in autumn 1976 was as follows: big bluestem, Andropogon gerardi (17\%); bush clover, Lespedeza cuneata (16\%); ironweed, Vernonia spp. (12\%); Indian grass, Sorghastrum nutans (10\%); milkweed, Asclepias spp. $(9 \%)$; goldenrod $(9 \%)$; bluegrass $(5 \%)$; switch grass, Panicum spp. (5\%); blackberry, Rubus spp. (2\%); little bluestem, Andropogon scoparius $(2 \%)$; and about 10 other species with a relative abundance less than $1 \%$.

The only other small mammal that occurred more than sporadically on the study areas was the short-tailed shrew, Blarina brevicauda. Mammalian predators occurring on the study areas were: raccoon, Procyon lotor; least and long-tailed weasels, Mustela nivalis and $M$. frenata; striped skunk, Mephitis mephitis; gray fox, Urocyon cinereoargenteus; and domestic cat, Felis catus. Other predators included: great-horned owl, Bubo virginianus; red-tailed hawk, Buteo jamaicensis; marsh hawk, Circus cyaneus; and fox snake, Elaphe vulpina.

\section{METHODS}

(Each study area was gridded at a 10-m interval (140 stations in alfalfa, 225 in bluegrass, and 247 in prairie). One wooden multiple-catch live-trap ( $\mathrm{urt}, 1940$ ) was placed at each station. A 2-day prebaiting period was followed by a 3-day trapping session during which traps were checked in early morning and late afternoon. Cracked corn was used for prebaiting and as food during the trapping periods. Cotton was placed in the traps for insulation during cold periods $\left(<-15^{\circ} \mathrm{C}\right)$; traps were covered with vegetation during the summer. Trap mortality was less than $0.5 \%$ throughout the study. We began trapping the bluegrass field in August 1971 and the prairie and alfalfa areas in March and May 1972, respectively. Each area was trapped once a month through July 1975; thereafter they were trapped at 3 -week intervals.

Individuals were toe clipped for identification at first capture (no more than two toes on any foot). The following information was obtained at each capture: station, ar.imal number, sex, reproductive condition (females: vulva open or closed, pregnant, lactating; males: testes scrotal or abdominal), presence of scars, and body weight. Age classes defined in the present study were based on observations of weights of reproductively active laboratory reared and field captured animals; these insluded: juvenile $(<20 \mathrm{~g}$, males and females), subadult $(20-30 \mathrm{~g}$, males; $20-\mathbf{2 8} \mathrm{g}$, fenales), and adult ( $>30 \mathrm{~g}$, males; $>28 \mathrm{~g}$, females).

Population density for each trapping session on each study area was based upon the minimum number known to be alive. The estimates were corrected for animals present, but not captured. Trappability (percent of the animals known to be presen: that were actually captured in a given trapping session) was high for both species in all three areas throughout the year. Mean values and ranges of trappability were: prairie, $95(82-100) \%$, bluegrass, $91(73-100) \%$; alfalfa, $87(67-100 \%$. H i 1 - 
bor $\mathrm{n}$ et al. (1976) indicated that trappability greater than $80 \%$ (when using the minimum known alive method) only slightly underestimates population densities. B o onstra \& Krebs (1977) have reported low trappability for juvenile Microtus townsendi. However, captures in 30 pitfall traps set at random in the bluegrass area during a live-trapping session when numerous young $M$. pennsylvanicus were present indicated juveniles of this species did not avoid our traps (M. ochrogaster juveniles were not present in the population at this time, however). We therefore feel the densities presented in this paper represent reasonably accurate estimates of the number of active animals present each trapping session.

\section{WEATHER PATTERNS}

General climatic trends and summaries of temperatures and precipitation during this study have been complied from records of the U. S. Weather Bureau station in Champaign, IL (10 km the study areas). These have been compared with norms for the period 1889-1970 (annual precipitation $91 \mathrm{~cm}$, highest April-July; frost-free period approximately 181 days, mid-April to mid-October).

1972. The year was characterized by slightly normal precipitation and below normal temperatures. Much of the precipitation occurred during the period AugustDecember. In mid-December a severe freezing rain covered the study areas with ice which remained for several weeks due to low temperatures.

1973. Precipitation and temperatures were both above normal. This was the second wettest year on record and water stood over much of the study areas from early spring through mid-July. An unusually heavy snowfall $(30 \mathrm{~cm})$ occurred in mid-December. Freezing rain, followed by low temperatures in late December, produced a 5-10 cm deep "slush * which was frozen to the surface of the study areas; the ice remained until late February 1974.

1974. Precipitation was well above normal in 1974, while temperatures were essentially normal. Due to melt-off of ice and above normal rainfall, the study areas were flooded from early spring until late June. This was followed by a hot, dry period in mid-summer. A hard freeze in mid-September killed most of the herbaceous vegetation. Snowfall during winter 1974-1975 was above normal.

1975. During 1975 precipitation was again above normal. Spring temperatures were low; vegetative growth on the study areas began 3-4 weeks later than usual. High temperatures in late May resulted in a sudden transition from early spring to mid-summer vegetation conditions. The growing season was approximately one month longer than normal, extending into mid-November. Snowfall in November and December was usually heavy.

1976. The year was generally below normal in both precipitation and temperature. However, late winter-early spring temperatures were well above normal; growth of monocots accordingly began very early on the study areas.

\section{POPULATION FLUCTUATIONS}

Two complete population cycles of $M$. ochrogaster were observed during this study. Fluctuations of prairie vole populations in all three areas were essentially synchronous (Fig. 1). The first cycle was studied from the beginning of the increase phase, except in the alfalfa area where trapping was begun $6-8$ weeks after the estimated start of the increase. 
Numbers in all areas had declined to very low levels by December 1976 and subsequent trapping has revealed no substantial increases in any area through 1978. We therefore conclude that the second cycle of $M$. ochrogaster ended in early winter $1976-77$ and that we present complete data for this cycle.

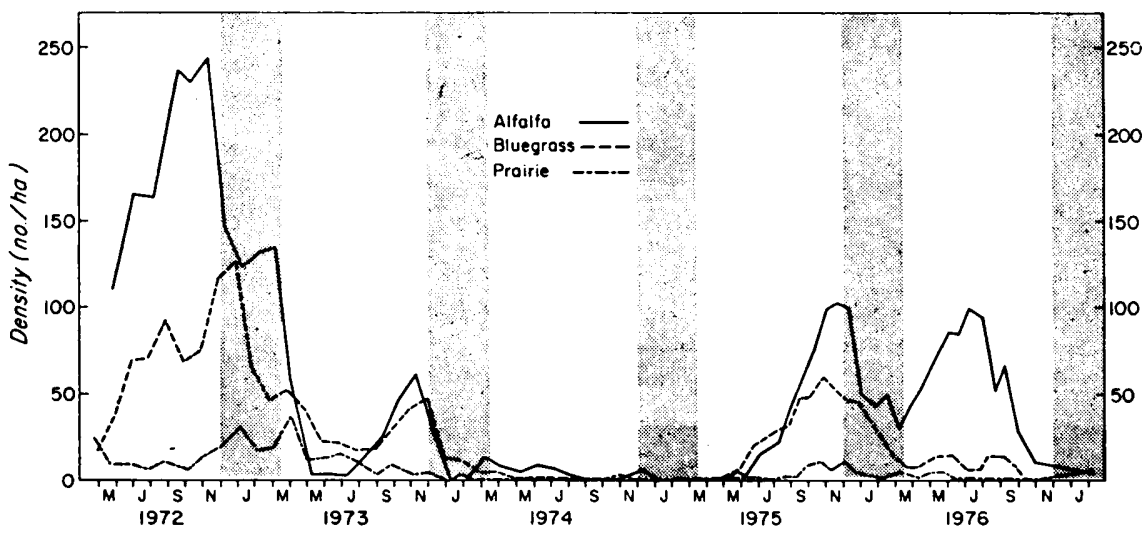

Fig. 1. Population densities of Microtus ochrogaster in the three main study areas. Winter periods are shaded.

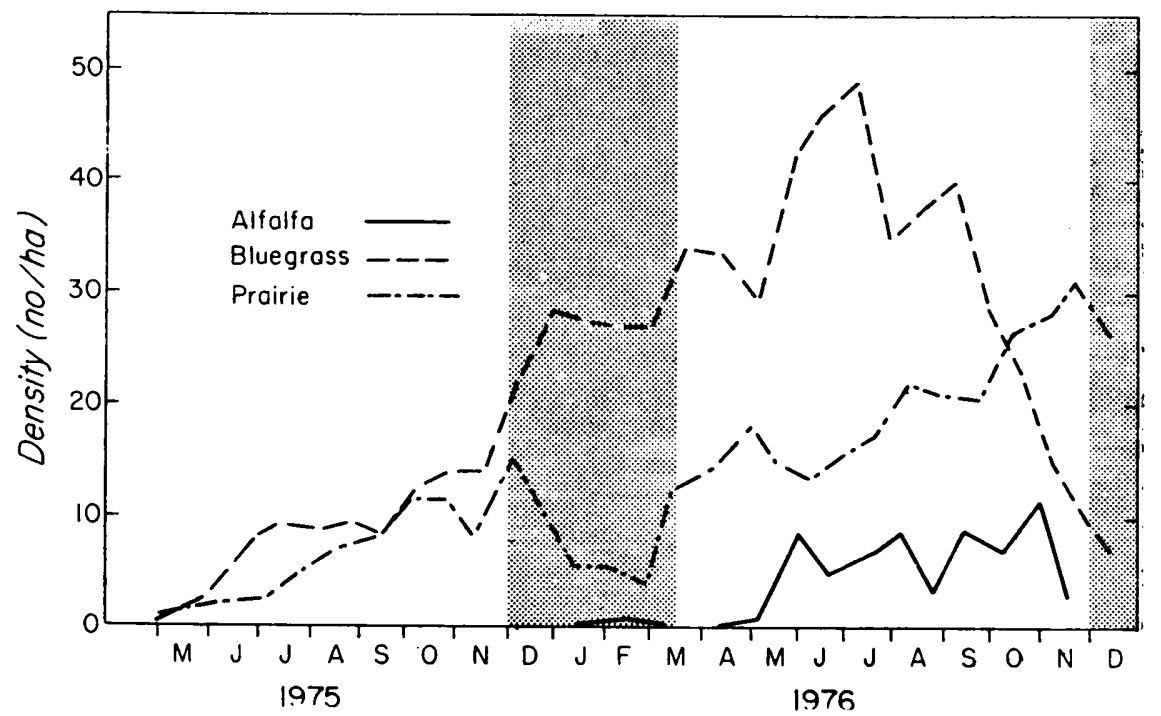

Fig. 2. Population densities of Microtus pennsylvanicus in the three study areas. The species entered the region in May 1973; it occurred only sporadically until May 1975. Winter periods are shaded.

Only one population cycle of $M$. pennsylvanicus was observed. This species entered the study region via dispersal along interstate highways 
in 1973 (G e t $\mathrm{z}$ et al., 1978). Meadow voles appeared in the prairie in May 1973; they were first captured in the bluegrass area in November 1973. By late $1975 \mathrm{M}$. pennsylvanicus had become the most abundant vole in these two areas. The species did not become established in the alfalfa area until late 1976.

Fluctuations of meadow vole populations in the prairie and bluegrass areas were partially in phase (Fig. 2). The cycle in the bluegrass area ended in late 1976. Microtus pennsylvanicus did not decline in the prairie area in 1976-77; densities remained high until the area was burned in April 1977. Population density of $M$. pennsylvanicus in an adjacent prairie habitat declined in spring 1977. No subsequent increase of this species was observed in the bluegrass and prairie habitats by March 1979. Microtus pennsylvanicus increased in the alfalfa only after the grasses became dominant in the area. Another area with a relatively pure stand of alfalfa displayed low, erratic fluctuations of $M$. pennsylvanicus from January 1977-March 1979.

There was no evidence of population synchrony between the two species of Microtus in either the bluegrass or prairie areas. That they were slightly out of phase may be a result of interspecific interactions; this possibility is currently being investigated by manipulative field studies.

\section{DEMOGRAPHIC FACTORS}

\subsection{Survival}

Disappearance from an area is a combination of mortality and emigration. Verner (1978) found emigration losses from the bluegrass area to be less than $10 \%$ for both species. Therefore we assumed disappearance of animals from our study areas to be primarily the result of in situ mortality.

We employed several methods of analyzing survival: (1) Persistence of individuals on each study area. We assumed that an individual entered a population midway between the trapping session in which it was first captured and the preceding session, and left the population midway to the trapping period following its last capture. (2) Survivorship of animals after first capture. (3) Life expectancy following first capture as a juvenile (estimated by the Leslie-Ranson method; Leslie et al., 1955). (4) Survival from birth to trappable age, as calculated by use of a modified version (Appendix I) of formulas described by $\mathrm{Bujalska}$ et al. (1968). (5) Survival per 28 days (calculated from survival rates between consecutive trapping periods). 


\section{PERSISTENCE ON STUDY AREA}

$M$. ochrogaster. Survival of this species was highest in the alfalfa area and lowest in the prairie. Except for males first caught as adults, mean persistence of all sex-age classes was approximately one week longer in the alfalfa area than in the bluegrass area and one week longer in the bluegrass than in the prairie area (Table 1). Survivorship curves for all age classes were significantly lower in the prairie than in the other areas $(p<.05$, Kolmogorov-Smirnov test; S i e g e 1, 1956); no difference was

\section{Table 1}

Average number of weeks individuals of Microtus ochrogaster and $M$. pennsylvanicus remained on study areas. Data are for entire study, March 1972 - December 1976. Number of individuals in parentheses.

\begin{tabular}{|c|c|c|c|c|c|c|}
\hline \multirow{2}{*}{$\begin{array}{c}\text { Age at First } \\
\text { Capture }\end{array}$} & \multirow[t]{2}{*}{ Sex } & \multicolumn{3}{|c|}{ M. ochrogaster } & \multicolumn{2}{|c|}{ M. pennsylvanicus } \\
\hline & & Alfalfa & Bluegrass & $\overline{\text { Prairie }}$ & Bluegrass & Prairie \\
\hline \multirow[t]{2}{*}{ Adult } & Male & $8.1(565)$ & $7.8(474)$ & $8.0(112)$ & $8.6 \quad(99)$ & $9.9(99)$ \\
\hline & Female & $8.7(602)$ & $7.8(506)$ & 6.5 (111) & 9.8 (147) & $9.4(66)$ \\
\hline \multirow[t]{2}{*}{ Subadult } & Male & 7.4 (196) & $6.6(249)$ & $5.7 \quad(70)$ & $8.2(47)$ & $7.2(58)$ \\
\hline & Female & $8.2(156)$ & $7.3(200)$ & (62) & (51) & 7.1 (47) \\
\hline \multirow[t]{2}{*}{ Juvenile } & Male & $7.4(238)$ & $6.3(193)$ & (50) & (60) & $5.6(30)$ \\
\hline & Female & $7.4(260)$ & 6.8 (194) & (49) & (65) & $8.1(36)$ \\
\hline
\end{tabular}

found between survival curves of $M$. ochrogaster in the bluegrass and alfalfa areas. Life expectancy following capture as a juvenile was approximately one week longer in the alfalfa area than in the bluegrass and one week longer in the bluegrass than in the prairie. The estimated percent survival, from birth to trappable age over the entire study period was as follows: alfalfa, 6.5; bluegrass, 15.3; and prairie, 41.0 (4845, 1961, and 350 estimated births, respectively).

There was no significant difference between sexes in mean persistence on the three study areas (Table 1), although survival times for females were often slightly longer than those of males. Survivorship curves of males and females in each age class did not differ significantly, except in the blugrass area where female subadults had higher survival during the first cycle and female juveniles had higher survival during the second cycle $(p<.01$, Kolmogorov-Smirnov test). There was also no significant difference between sexes in life expectancy following first capture as a juvenile on any of the study areas (Table 2).

$M$. pennsylvanicus. There was no marked difference in average survival times of this species between the two habitats (Table 1), nor was there a significant difference in survivorship curves for each age-class (Kolmogorov-Smirnov test). Life expectancies following first captures as 
a juvenile (sexes combined) were $4.1 \pm .1 \quad(\mathrm{~N}=125)$ and $4.5 \pm .2(\mathrm{~N}=66)$ weeks in the bluegrass and prairie areas, respectively. Estimated survival from birth to trappable age was $24.9 \%$ in the bluegrass area and $46.3 \%$ in the prairie ( 1.115 and 520 estimated births, respectively).

Table 2

Average life expectancy (no. weeks \pm 1 SE) of Microtus ochrogaster after first capture as a juvenile (approximately 3 weeks of age). Data are for entire study; sample sizes in parentheses.

\begin{tabular}{lcc}
\hline \multicolumn{1}{c}{ Area } & \multicolumn{1}{c}{ Males } & Females \\
\hline Alfalfa & $4.30 \pm .03(238)$ & $4.48 \pm .03(260)$ \\
Bluegrass & $3.25 \pm .03(193)$ & $3.58 \pm .03(194)$ \\
Prairie & $2.15 \pm .09(50)$ & $2.25 \pm .09(49)$ \\
\hline
\end{tabular}

There was no consistent difference in mean persistence between sexes in the prairie area; females in the bluegrass area had slightly longer survival times than did males (Table 1). Survival rates did not differ significantly (Kolmogorov-Smirnov test) between sexes or among age classes in either area.

Comparison between species. Average persistence of $M$. pennsylvanicus (all age classes and sexes combined) on the bluegrass study area was $18 \%$ (1.3 wks) longer than that of $M$. ochrogaster; $M$. pennsylvanicus persisted $30 \%$ (1.9 wks) longer than $M$. ochrogaster in the prairie. Except for males first caught as juveniles in the bluegrass, all sex and age-classes of $M$. pennsylvanicus survived significantly longer than did $M$. ochrogaster ( $p>.05$, Kolmogorov-Smirnov test). The life expectancy of juvenile $M$. pennsylvanicus was significantly greater than that of $M$. ochrogaster in both areas (prairie: $4.48 \pm .145$ and $2.20 \pm .090 \mathrm{wks}$, $t=13.3, p<.001$; bluegrass: $4.14 \pm .106$ and $3.40 \pm .030$ wks, $t=6.72$, $p<.001)$.

\section{Seasonal Survival}

M. ochrogaster. No consistent seasonal pattern in 28-day survival rates of adults was evident in any study area during the first cycle (Fig. 3: Most changes in survival rates can be attributed to severe or unusual climatic conditions (see Discussion).

During the second cycle, however, differences in survival rates not attributable to weather were noted. A sharp decrease in survival durins autumn 1975 occurred in both the alfalfa and bluegrass areas (Fig. 4. Thereafter survival rates increased in the alfalfa area in midwinter, whil: 
remaining low in the bluegrass through the winter. There was also a marked decrease in survival in both these areas in spring 1976. There was no heavy rain during spring 1976 as occurred during the decrease in spring 1973.

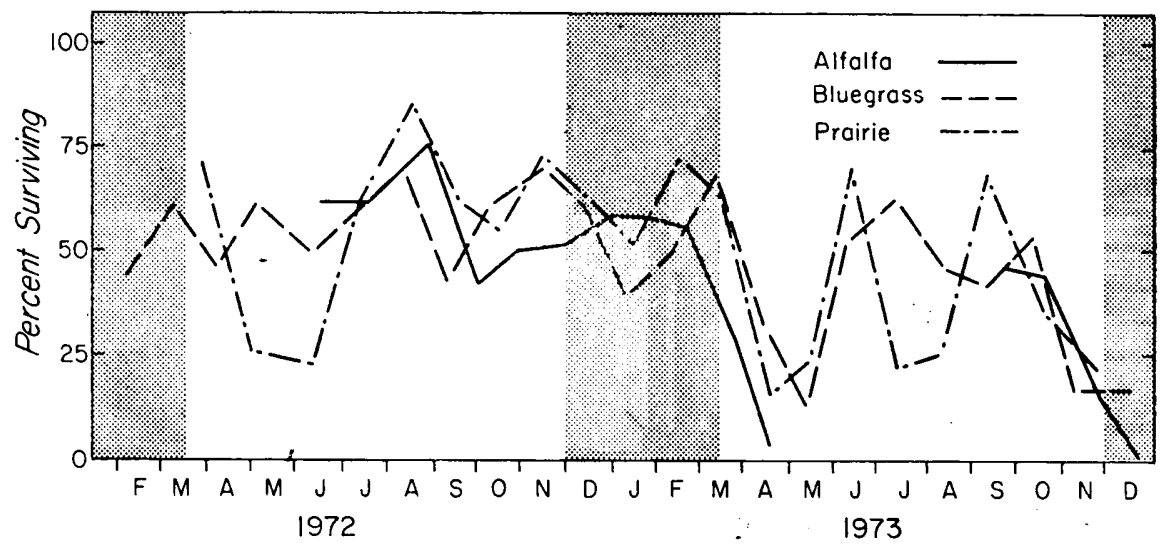

Fig. 3. Mean survival rate per 28 days for adult Microtus ochrogaster during the first population cycle. Data for males and females combined. Winter periods shaded.

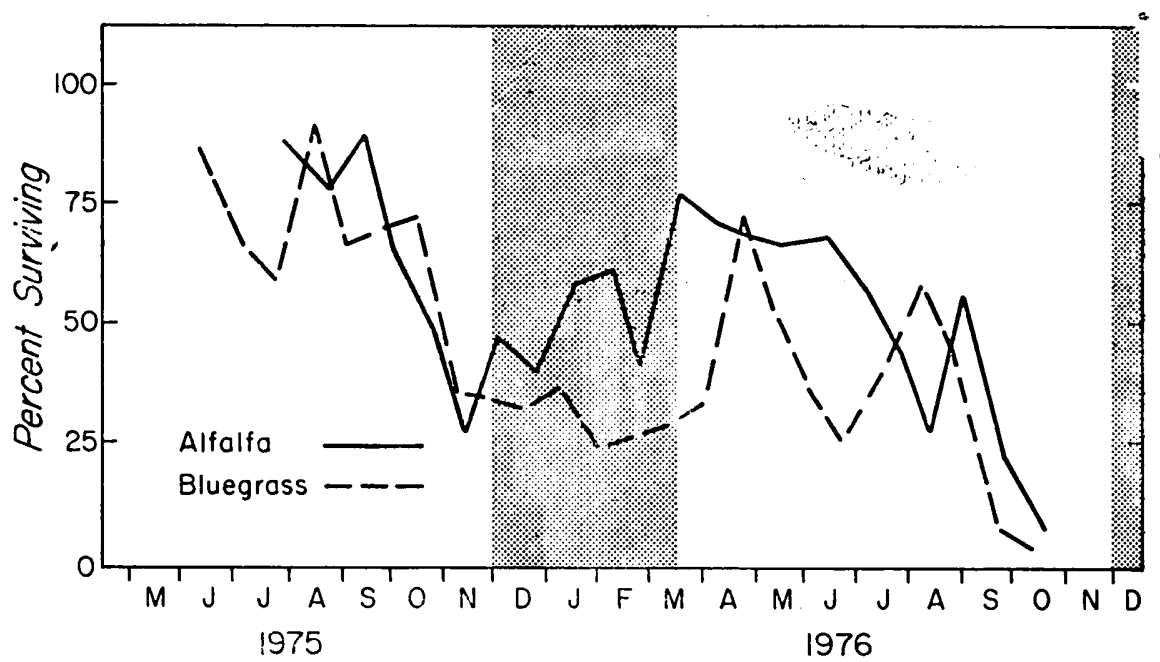

Fig. 4. Mean survival rate per 28 days for adult Microtus ochrogaster during second population cycle (sample sizes too small in prairie to provide meaningful data). Data for males and females combined. Winter periods shaded.

When average survival per 28 days was calculated on a seasonal basis over the entire study, no consistent trend was found between areas 
Table 3

Seasonal means in demographic factors for Microtus ochrogaster and $M$. pennsylvanicus. Data are for entire study, March 1972 -December 1976. Sample sizes in parentheses.

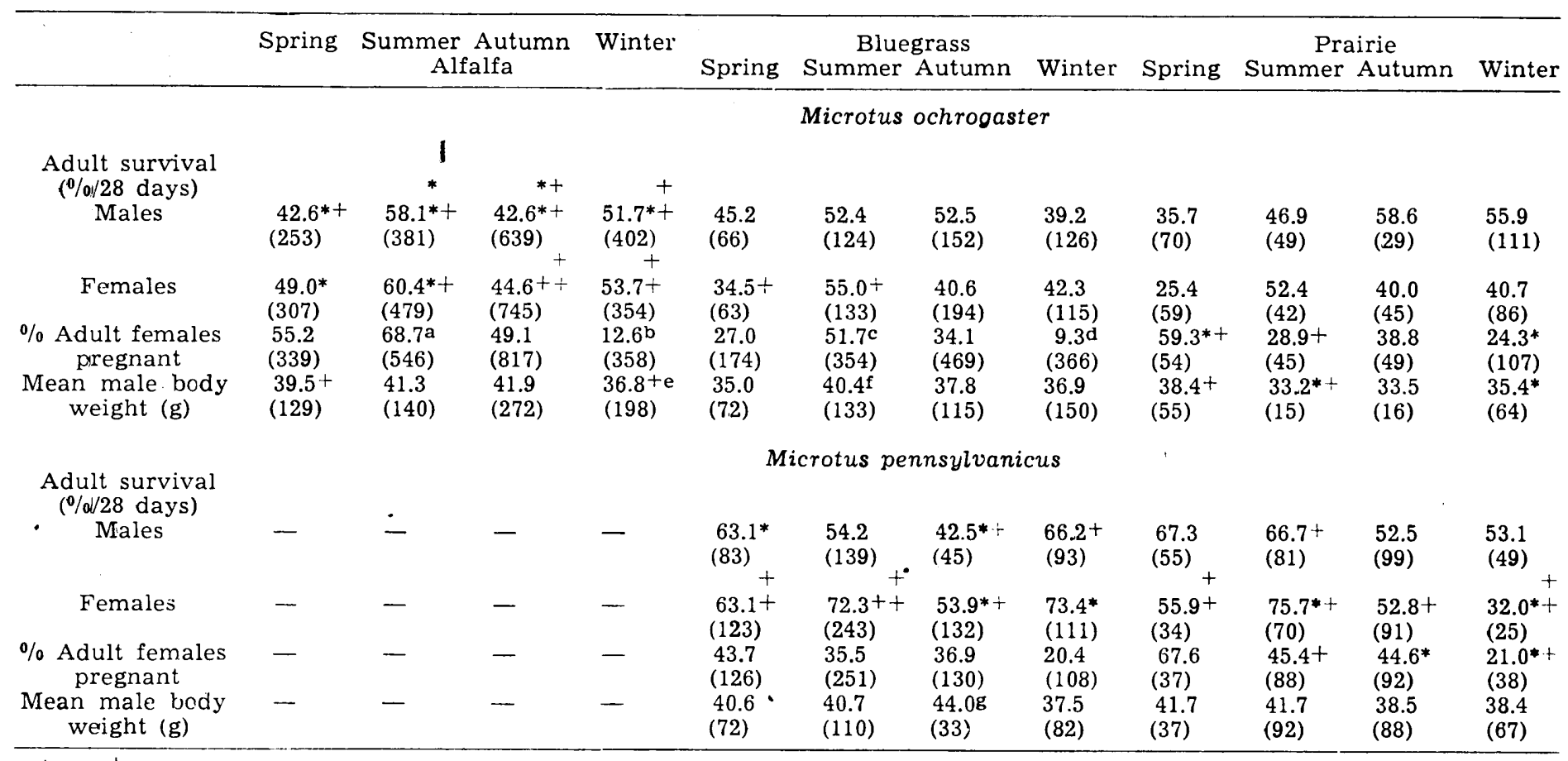

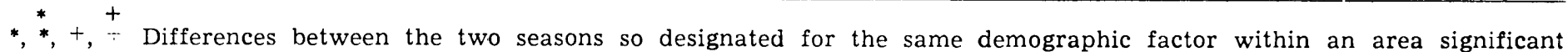
at least at the .05 level ( $t$-test).

$a, c, f$ Differences between summer and all other seasons significant at .05 level.

b, d Differences between winter and all other seasons significant at .05 level.

e Differences between winter and both summer and autumn significant at .05 level.

g Difference between autumn and other seasons significant at .05 level. 
(Table 3). Both female and male survival in the alfalfa area was significantly higher in summer than spring or autumn; differences between summer and winter survival were nearly significant $(p<.10)$. In the bluegrass area, survival of females was significantly greater during the summer than other season and lowest in spring. Summer and autumn survival of males was equally high and significantly greater than the low in winter. Female survival in the prairie was highest in summer while that of males was highest in autumn. Survival of both sexes was lowest in spring, significantly lower than summer survival of females and winter survival of males.

$M$. pennsylvanicus. Adequate survival data for $M$. pennsylvanicus are available only from summer 1975 through December 1976. These limited data did not indicate a consistent seasonal pattern between study areas in 28-day survival rates (Fig. 5).

When averaged on a seasonal basis, 28-day survival of females in the bluegrass area was significantly higher during the summer and winter than during autumn, when it was almost $20 \%$ lower (Table 3 ). The $9.2 \%$ difference between summer and spring female survival was significant. Male survival was also lowest in autumn, significantly lower than that

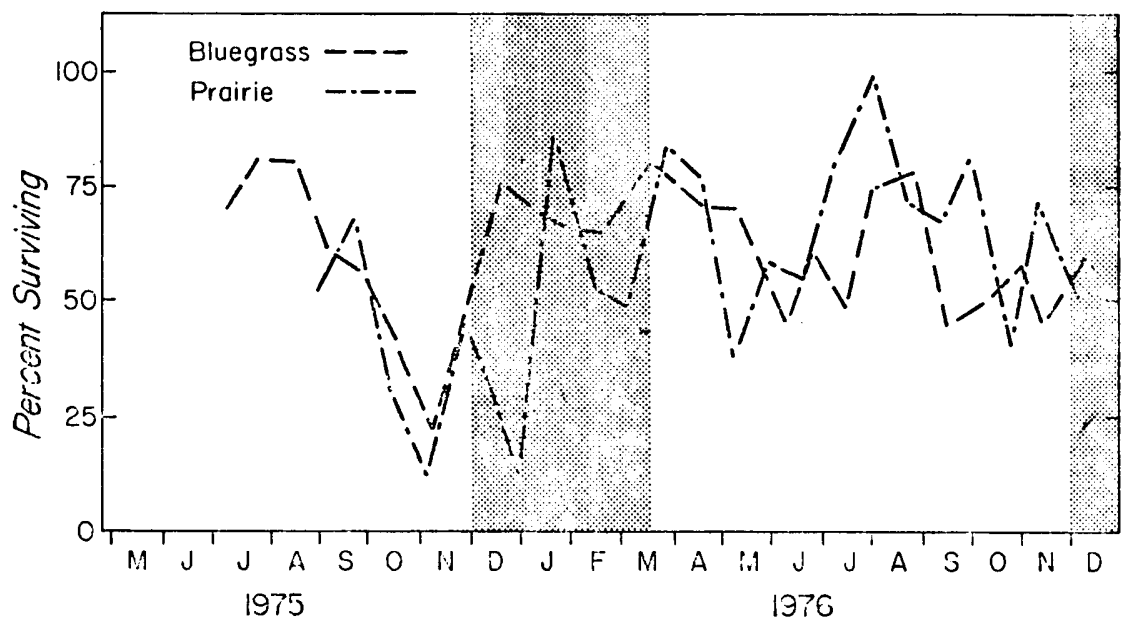

Fjg. 5. Mean survival rate per 28 days for adult Microtus pennsylvanicus. Data for males and females combined. Winter periods shaded.

during both spring and winter, which were approximately $20 \%$ higher. Ir. the prairie area, female survival was highest in summer, significantly greater than autumn and winter, when survival was lowest. Male surviv- 
al was $13-15 \%$ higher during spring and summer than fall and winter, but the difference was not significant.

Comparison between species. Due to low population densities of $M$. ochrogaster in the blugrass areas in 1976 and in the prairie area throughout the second cycle, only limited comparisons are possible between 28-day survival rates of the two species. In the bluegrass area both $M$. ochrogaster and $M$. pennsylvanicus experienced a decrease in survival in midautumn 1975. Survival rates of $M$. pennsylvanicus recovered rapidly in early winter and remained high throughout most of 1976, but survival of $M$. ochrogaster continued to fall throughout the winter and remained at low to moderate levels in 1976. In late 1976 28-day survival rates of the few $M$. pennsylvanicus in the alfalfa area were relatively high $(>50 \%)$, whereas survival of $M$. ochrogaster decreased sharply to $<10 \%$.

\section{Survival and Phase of Cycle}

Due to the brief periods of "peak" densities and very small sample sizes from the low phases, only data from the increase and decline phases of the population cycle have been compared. Data from one trapping session on each side of a "peak « were excluded from the analyses: likewise, data for the first trapping period of an increase were not included.

The increase and decline phases of the population cycles were distinct for all populations except the second $M$. ochrogaster cycle in the alfalfa (Figs. 1 and 2). We interpret the second "peak " in summer 1976 to represent a type $\mathrm{M}$ decline ( $\mathrm{C}$ i $\mathrm{t} t \mathrm{y}, 1955)$; such declines typically display increases in numbers, frequently equaling the peak density. Body weights of adult males during summer 1976 were significantly lower than during the 1975 peak ( $35.0 \pm 0.9$ and $39.8 \pm 1.1 \mathrm{~g}$, respectively); daily individual growth rates were also less $(0.05$ and $0.79 \mathrm{~g} /$ day, respectively) (C o l e \& $\mathrm{B}$ a t z li, In Press). These are indicators of a decline phase; the period of December 1975 through December 1976 is considered a decline phase in this population.

$M$. ochrogaster. Adult survival per 28 days of both sexes was significantly greater during the increase than during the decline phases in all three study areas, with the exception of the second cycle in the alfalfa area (Table 4).

Survival to trappable age was slightly higher in the increase than during the decline phases in all three areas (Table 4). Life expectaricy of juveniles was also greater during the increase than during the decline phase in all three areas; differences in the alfalfa and bluegrass areas were significant at the .05 level (Table 4). 
Table 4

Comparison of demografhic factors of Microtus ochrogaster between increase (Inc) and decline (Dec) phases of the population cycle. First cycle, March 1972-May 1973; second cycle, June 1975-December 1976. Sample sizes in parentheses.

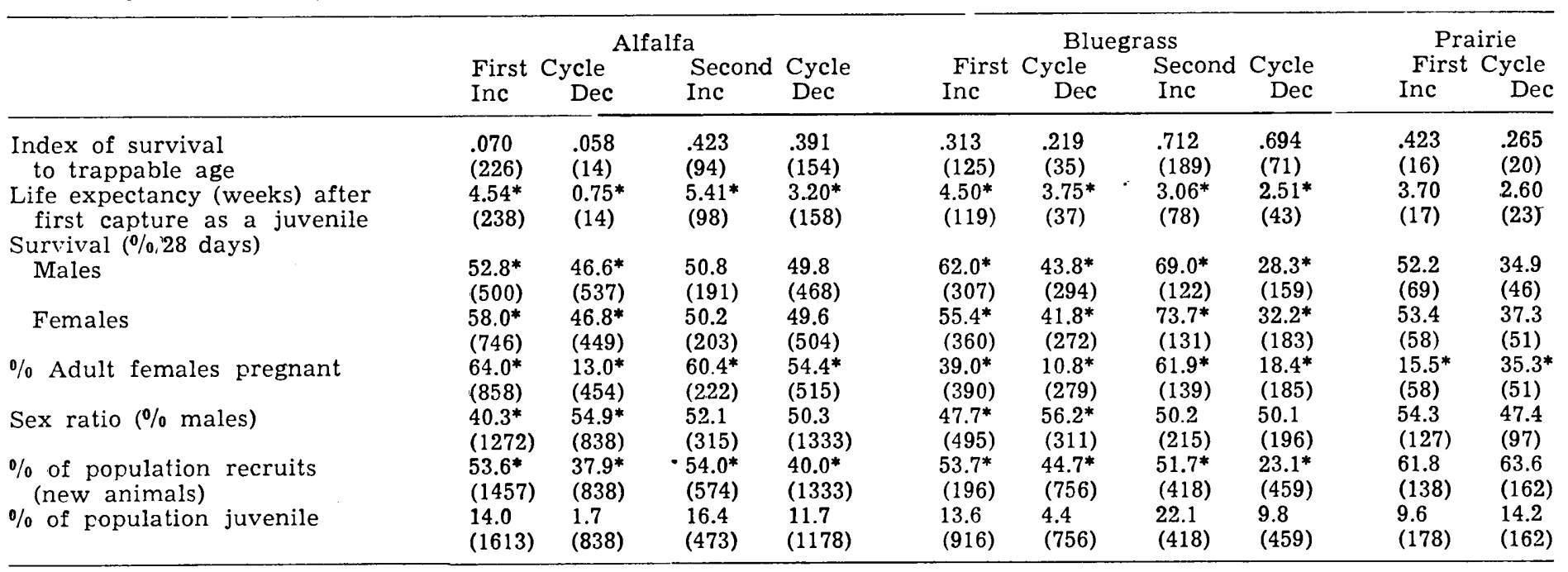

* Difference between increase and decline phases significant at least at .05 level ( $t$-test). 
M. pennsylvanicus. Phase comparisons were not possible in the prairie area, since no decline phases was recorded for this population. In the bluegrass area, there was no significant difference in survivorship of

Table 5

Comparison of demographic factors of Microtus pennsylvanicus between phases of the population cycle in the bluegrass area, June 1975 - December 1976.

Sample sizes in parentheses.

\begin{tabular}{lccc}
\hline & Increase & Decline & $\begin{array}{c}\text { Statistical } \\
\text { Significance } \\
\text { (t-test) }\end{array}$ \\
\hline $\begin{array}{l}\text { Index of survival to trappable age } \\
\begin{array}{l}\text { Life expectancy (weeks) } \\
\text { after first capture as a juvenile }\end{array}\end{array}$ & $.528(68)$ & $.230(37)$ & $<.05$ \\
\% Survival per 28 days & $6.8(68)$ & $1.0(37)$ & $<.001$ \\
$\quad$ Males & $61.2(230)$ & $53.3(92)$ & $\mathrm{NS}$ \\
Females & $68.0(307)$ & $66.4(219)$ & $\mathrm{NS}$ \\
$\%$ Adult females pregnant & $33.9(316)$ & $32.6(224)$ & $\mathrm{NS}$ \\
Sex ratio (\% males) & $43.7(716)$ & $31.8(319)$ & $<.01$ \\
$\%$ of population recruits & $50.6(239)$ & $34.3(99)$ & $<.01$ \\
$\%$ of population juveniles & $12.8(91)$ & $10.3(40)$ & $\mathrm{NS}$ \\
\hline
\end{tabular}

adult $M$. pennsylvanicus between increase and decline phases (Table 5). Mean life expectancy of individuals first caught is juveniles during the increase phase was significantly greater ( $t$-test, $p<.001)$ than during the decline. Survival to trappable age was twice as likely during the increase as during the decline.

\section{Survival and Population Density}

Comparisons of survival and population density were made to detect any possible correlations indicative of a negative feedback population regulatory mechanism. Since there may be a lag time in the expression of the effects of population density, correlations were also made between density and 28-day survival rates 4.5 and 9 weeks later for the first cycle and 3,6 , and 9 weeks later for the second cycle.

In general, there was a positive correlation between population density and survival $3-9$ weeks later (Table 6).

$M$. ochrogaster. During the first cycle there was a positive (but not significant) correlation between population density and survival per 28 days of both adult males and females up to 9 weeks later in all three areas (Table 6). During the second cycle, however, there was a negative (non significant) correlation between population density and survival 9 weeks later of both sexes in the bluegrass and alfalfa areas; too few data were available from the prairie for statistical analysis. 
Comparisons of juvenile survival (survival to trappable age) with total population density and with the number of adult males and females in the bluegrass and prairie areas yielded no significant correlation. In the alfalfa area there was a significant $(p<.05)$ negative correlation between the numbers of both adult males and females and juvenile survival ( $r=-0.360$ and -0.336 , respectively).

Table 6

Correlation coefficients $(r)$ of population density with various demographic factors of Microtus ochrogaster (Mo) and $M$. pennsylvanicus (Mp). First cycle, March $1972-$ May 1973; second cycle, June 1975 - December 1976.

\begin{tabular}{|c|c|c|c|c|c|c|}
\hline \multirow{2}{*}{$\begin{array}{c}\text { Population density } \\
\text { vs. }\end{array}$} & \multirow[b]{2}{*}{ Cycle } & \multicolumn{2}{|c|}{ Bluegrass } & \multirow{2}{*}{$\begin{array}{l}\text { Alfalfa } \\
\text { Mo }\end{array}$} & \multicolumn{2}{|c|}{ Prairie } \\
\hline & & Mo & $\mathrm{Mp}$ & & Mo & $\overline{\mathrm{Mp}}$ \\
\hline Average body weight, same period & $\begin{array}{l}1 \\
2\end{array}$ & $\begin{array}{l}.684 * * \\
.858 * *\end{array}$ & $-\overline{486 *}$ & $\begin{array}{r}.181 \\
-.403\end{array}$ & $\stackrel{.429}{-}$ & $-\overline{369}$ \\
\hline$\%$ ㅇ Pregnant, same period & $\begin{array}{l}1 \\
2\end{array}$ & $\begin{array}{r}-.320 \\
.103\end{array}$ & $\overline{.384 *}$ & $\begin{array}{l}.229 \\
.032\end{array}$ & -.198 & $-\overline{388 *}$ \\
\hline$\%$ o Pregnant, 9 weeks later & $\begin{array}{l}1 \\
2\end{array}$ & $\begin{array}{l}-.377 \\
-.606 * *\end{array}$ & $\overline{.093}$ & $\begin{array}{l}-.472 \\
-.701^{*}\end{array}$ & .406 & $-\overline{580 *}$ \\
\hline$\%$ Survival, $3-4.5$ weeks later & $\begin{array}{l}1 \\
2\end{array}$ & $\begin{array}{l}.086 \\
.339\end{array}$ & $\overline{.141}$ & $\begin{array}{l}.928 * * \\
.435^{*}\end{array}$ & -.168 & $\overline{.239}$ \\
\hline$\%$ ơ Survival, $3-4.5$ weeks later & $\begin{array}{l}1 \\
2\end{array}$ & $\begin{array}{l}.034 \\
.313\end{array}$ & $\overline{199}$ & $\begin{array}{l}.891 * * \\
.671 * *\end{array}$ & .464 & $\overline{214}$ \\
\hline \% $\sigma^{\prime}$ Survival, 9 weeks later & $\begin{array}{l}1 \\
2\end{array}$ & $\begin{array}{r}.143 \\
-.382\end{array}$ & $\overline{.074}$ & $\begin{array}{r}.501 \\
-.441\end{array}$ & .331 & $\overline{.370}$ \\
\hline \% 우 Survival, 9 weeks later & $\begin{array}{l}1 \\
2\end{array}$ & $\begin{array}{r}.349 \\
-.247\end{array}$ & $-\overline{307}$ & $\begin{array}{r}.311 \\
-.372\end{array}$ & 206 & $\overline{.165}$ \\
\hline $0_{0}$ \& Pregnant, 9 weeks earlier & $\begin{array}{l}1 \\
2\end{array}$ & $\begin{array}{c}-.007 \\
.497 *\end{array}$ & $-\overline{185}$ & $\begin{array}{l}.470 * \\
.579 *\end{array}$ & $-.556^{*}$ & $\overline{.097}$ \\
\hline$\%$ on Survival, 9 weeks earlier & $\begin{array}{l}1 \\
2\end{array}$ & $\begin{array}{l}.451^{*} \\
.485^{*}\end{array}$ & $\overline{.178}$ & $\begin{array}{l}.675^{* *} \\
.498^{*}\end{array}$ & .332 & $\overline{.497 *}$ \\
\hline$\%$ \% Survival, 9 weeks earlier & $\begin{array}{l}1 \\
2\end{array}$ & $\begin{array}{l}.376 \\
.410\end{array}$ & $\overline{.013}$ & $\begin{array}{l}.631^{*} \\
.418\end{array}$ & .286 & $\overline{.357}$ \\
\hline
\end{tabular}

* Significant at .05 level; ** Significant at .01 level

M. pennsylvanicus. There was no significant correlation, or even a consistent trend, between population density and survival of adult male and female $M$. pennsylvanicus in either study area (Table 6). Survival of juveniles was not correlated with total population density or with number cf adult males in either area, but there was a significant correlation $(r=-0.584, p<.01)$ between adult female population density and juvenile survival in the bluegrass area.

\subsection{Reproduction}

Reproductive activity within the populations was determined by the rresence of pregnant females. Percent pregnancy during a given trapping. 
period also included voles present in the study area and not recorded as pregnant, but which were lactating during the following trapping session. These individuals in most cases had been pregnant the earlier trapping session, but in too early a stage to be dected.

\section{Seasonal Trends}

M. ochrogaster. The level of reproduction was significantly lower in winter than during any other season in the alfalfa and bluegrass areas. In the prairie area, the winter level was only significantly lower in comparison to that of spring, when the proportion of pregnant females was highest. Reproductive levels in the alfalfa and bluegrass areas were significantly higher in summer than during other seasons (Table 3).

Midwinter reproductive levels were lower in all habitats during the 1972-73 cycle than during the $1975-76$ cycle. Summer declines in reproduction observed during the first cycle in the bluegrass and prairie areas were not evident during the second cycle (Figs. 6 and 7).

The onset of increased reproductive activity occurred earlier (late February-early March) in the alfalfa and prairie areas than in the bluegrass area (late April-mid May). Declines in the level of reproduction

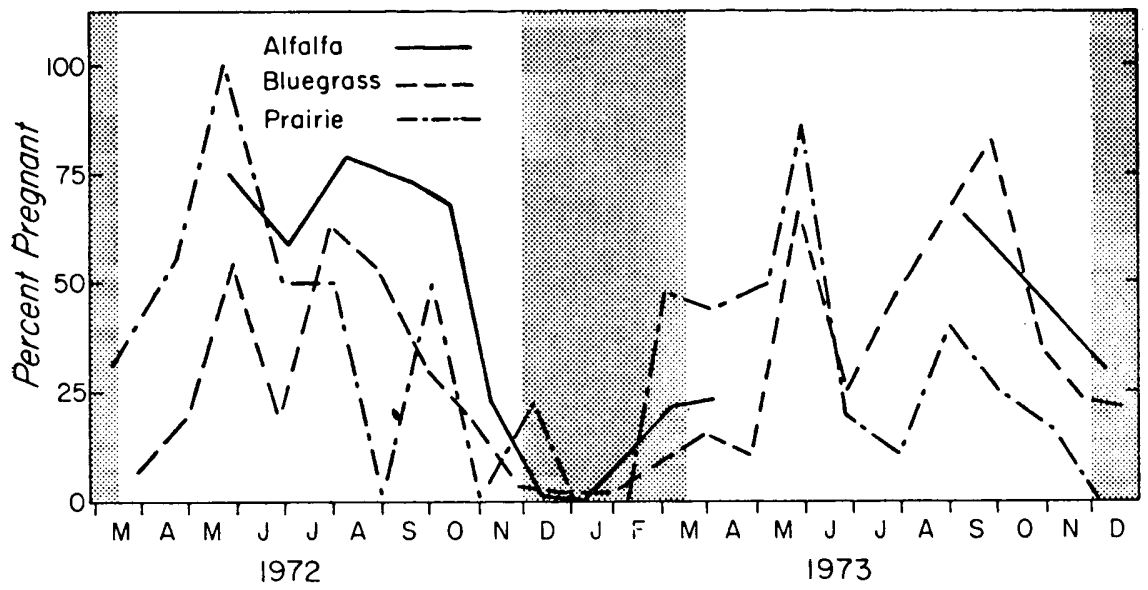

Fig. 6. Percent of female Microtus ochrogaster pregnant during first population cycle. There were too few animals present April - August 1973 in the alfalfa for meaningful analysis. Winter periods shaded.

appeared first (early summer) in the prairie area, next (midautumn) in the bluegrass, and last (late autumn) in the alfalfa (Figs. 6 and 7).

$M$. pennsylvanicus. This species also displayed a significant decrease in the proportion of pregnant females during winter (Table 3; Fig. 8). 
The level of reproduction increased rapidly in mid-February in both habitats, however. There was a marked decrease in reproduction in the prairie population during summer 1976, followed by an autumn increase; the bluegrass population exhibited a smaller summer reproductive decline without an autumn recovery.

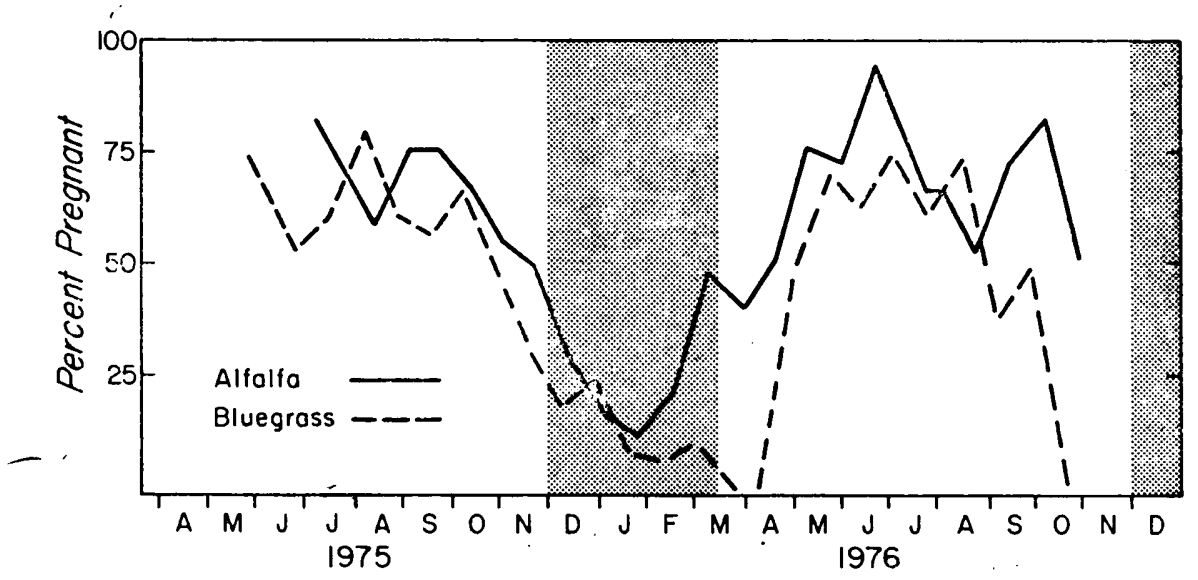

Fig. 7. Percent of female Microtus ochrogaster pregnant during second population cycle. There were too few animals in the prairie for meaningful analysis. Winter periods shaded.

Comparison of two species. Reproduction of $M$. pennsylvanicus started much earlier in the bluegrass habitats in 1976 than did that of $M$. ochrogaster (Figs. 7 and 8); adequate comparative data are not available for the prairie population. The general level of reproduction of $M$. pennsylvanicus during the 1975 and 1976 breeding seasons was somewhat lower than that of $M$. ochrogaster in the bluegrass habitat.

\section{Reproduction and Phase of Cycle}

Reproductive data for increase and decline phases of the population cycle were calculated in the same manner as the analysis of sirvival data (see above).

$M$. ochrogaster. The percentage of reproductive females was significantly greater during the increase than during the decline phase of both cycles in the alfalfa and bluegrass areas, although the difference was much less pronounced during the second cycle in the alfalfa area (Table 4). However, the percentage of reproductive females in the prairie area was significantly lower during the increase than during the decline phase. 
M. pennsylvanicus. There was no significant difference in the percentage of pregnant females between the increase and decline phases of the population cycle in the bluegrass area (Table 5). The data for the prairie area could not be categorized by phase.

\section{Reproduction and Population Density}

M. ochrogaster. Comparisons of population density of $M$. ochrogaster and the proportion of pregnant females 9 weeks later revealed negative,

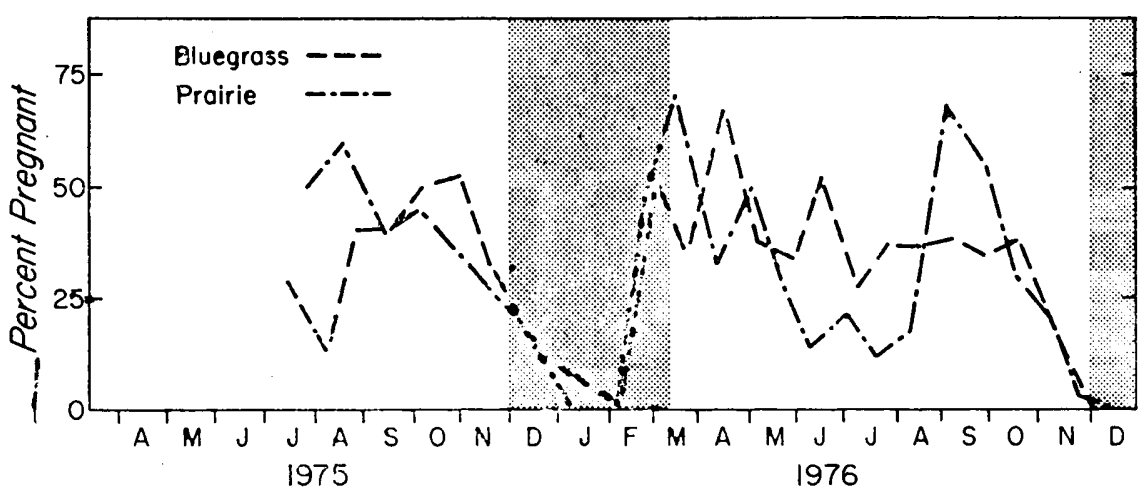

Fig. 8. Percent of female Microtus pennsylvanicus pregnant. Winter periods shaded.

but nonsignificant correlations during the first cycle in the alfalfa and bluegrass areas and significant, negative correlations during the second cycle in both areas (Table 6). There was a positive (nonsignificant) correlation between population density and reproduction 9 weeks later in the prairie area.

$M$. pennsylvanicus. In the bluegrass area population we found a significant $(p<.05)$ positive correlation between population density and the proportion of pregnant females during the same trapping period. However, there were no significant correlations of density with reproductive levels 3,6 or 9 weeks later. In the prairie population, significant $(p<.05)$ negative correlations were found between population density and reproduction during the same trapping period and 9 weeks later (Table 6).

\subsection{Body Weights}

Due to the complicating effects of pregnancy, only data for males have been used in analysis of body weights for this study. 
$M$. ochrogaster. During the autumn, at the end of the vegetation growing season, body weights of adult males were greatest in the alfalfa, intermediate in the bluegrass, and least in the prairie (Table 3 ). These differences were significant at the .05 level (one-way ANOVA). During the winter there was no significant difference in mean body weights of $M$. ochrogaster among the study areas. Body weight was significantly lower in the bluegrass area than in the.other two areas during spring and significantly lower in the prairie area during summer.

In the alfalfa area, mean body weights were highest in summer and autumn and lowest in winter. Mean body weights in the bluegrass area were highest in summer and lowest in spring. Highest mean body weights were recorded in spring and the lowest in summer and autumn in the prairie area. Therefore, the condition of $M$. ochrogaster appeared to be poorest during the spring in the bluegrass area, during the summer and autumn in the prairie, and during the winter in the alfalfa.

In the bluegrass area, there was a highly significant positive correlation $(p<.01)$ between population density and mean body weights of males during both cycles; in the prairie and alfalfa areas, there was a nonsignificant positive correlation. Highest body weights were recorded at the peaks of the cycles in the alfalfa and prairie areas; however, males in the bluegrass were heaviest in summer 1972, six months prior to the peak.

$M$. pennsylvanicus. During the autumn, male body weights of $M$. pennsylvanicus were significantly higher in the bluegrass area than in the prairie $(p<.01)$; there was no other seasonal difference in body weights between the two areas. In the bluegrass area body weights were lowest during the winter and highest during the autumn; in the prairie, autumn and winter weights were similar and significantly lower than spring and summer weights (Table 3 ). There was a negative correlation between population density and male body weight, which was significant in the bluegrass area but not in the prairie (Table 6).

\section{DISCUSSION}

\subsection{Amplitude of Fluctuations}

Among Populations

$M$. ochrogaster. Differences in both reproductive and survival patterns in the three habitats may have influenced the amplitude of fluctuations of $M$. ochrogaster densities. Reproduction commenced in early spring in both the prairie and alfalfa areas; reproduction dropped to low levels in late spring in the prairie area, but continued at a high level into late 
autumn in the alfalfa area. Reproduction in the bluegrass began later (late spring) than in the other two habitats and continued at a high level until early autumn. The early decrease in reproduction in the prairie area apparently prevented the populations from achieving more than modest densities. The long breeding season in the alfalfa area permitted the population to achieve very high densities, while the shorter period of reproduction in the bluegrass population resulted in peak densities intermediate between those of the alfalfa and prairie.

During periods of major reproduction activity there was no difference in the average proportion of females pregnant in the three populations.

Other reproductive factors which may have influenced the differences in amplitude on the three study areas were average litter size and age of first reproduction. Litter sizes of $M$. ochrogaster were significantly higher in the alfalfa than in the bluegrass habitats (5.1 and 3.7, respectively; Cole, 1977). Data from the prairie area are not available.

Differences in survival of $M$. ochrogaster among the three habitat types tended to reinforce reproductive effects, but did not in themselves appear responsible for the observed differences in amplitude of population fluctuations. Although overall persistence and life expectancy after first capture (as a juvenile) were greatest in the alfalfa and least in the prairie, survival of the young from birth to trappable age (the period during which most mortality occurs) was lowest in the alfalfa and highest in the prairie. There was also no consistent difference in seasonal survival rates of adults in the three areas that would account for differences in the observed amplitudes of population fluctuations of $M$. ochrogaster.

Levels of reproductive activity of $M$. ochrogaster populations in the three habitats were associated with differences in mean body weights of males. Body weights were high in the alfalfa and prairie areas in the spring. Whereas they remained high in the alfalfa area until winter, body weights in the prairie decreased in summer, the same time that reproductive activity dropped to low levels in that habitat. In the bluegrass area where reproductive levels were low throughout the spring, body weights remained low until early summer. Body weights are considered a direct indicator of quantity and quality of available food (C o l e \& B a t z li, In Press).

C o l e (1977) discusses the effects of food on general condition, survival and reproduction of $M$. ochrogaster. His results indicate food quality, not quantity, is a major factor in the observed demographic differences among populations in the three habitat types. The presence of particular species of dicots (especially alfalfa, clover, dandelion and plantain) is apparently an essential component of a high-quality $M$. ochrogaster habitat; grasses alone do not provide an optimal habitat. On the basis of 
our vegetation surveys there appears to be a gradient in habitat quality for $M$. ochrogaster from a high in the alfalfa area to a low in the prairie area. This sequence was indicated by differences in body weight and was reflected in reproductive and survival data. We conclude, therefore, that the difference in habitat quality was the underlying factor responsible for the observed differences in amplitude of fluctuation among study areas.

M. pennsylvanicus. Getz $(1961,1970)$ and Birney et al. (1976) have concluded that $M$. pennsylvanicus densities and amplitudes of fluctuations are related to the density of vegetative cover. The relatively sparse cover (especially in winter) in the alfalfa area appeared to be responsible for the low population densities of $M$. pennsylvanicus in this habitat throughout most of the study; the species became abundant in the alfalfa area only after grasses had become common.

Vegetative cover was more dense in the bluegrass area than in the prairie and this may have been reflected in demographic differences between the two populations of $M$. pennsylvanicus. Although average levels of survival and reproductive activity were similar, temporal differences in these factors appear responsible for the observed differences in population densities in these two habitats (Figs. 2, 5, and 8).

In early winter 1975-76, survival remained high in the bluegrass but decreased markedly in the prairie. Accordingly, population density continued to increase in the former area while it declined in the latter. Even though the percentage of pregnant females was high in the prairie in spring 1976, so few animals were present that numbers did not increase appreciably until early summer. During summer 1976 there was a decrease in reproduction in the prairie, but not in the bluegrass; thus, population density in the prairie dropped slightly. Reproductive activity increased in the prairie in early autumn 1976. Decreases in survival and reproductive activity during autumn 1976 coincided with the population decline in the bluegrass area.

There was no significant correlation between male body weight and survival or reproduction in either habitat. It would apper that food quality was not primarily responsible for the different population densitie: of $M$. pennsylvanicus. This conclusion is supported by supplemental feeding experiments in bluegrass and prairie habitats. Unlike $M$. ochrogaster, $M$. pennsylvanicus populations showed no numerical response to a supplemental food supply of alfalfa pellets (Cole \& B a tzli, 1978; G etz, unpubl. data). 
Between Cycles

Amplitudes of fluctuation of the three populations of $M$. ochrogaster during the first cycle were approximately double those of the second cycle. Peak densities during the first cycle were somewhat higher than those normally recorded for $M$. ochrogaster; those during the second cycle approximated densities observed in other studies ( $\mathrm{Krebs} \&$ M y e r s, 1974).

Several factors may have contributed to reduced population densities in the second cycle. One of these may have been a change in the level of predation. Except for the prairie, the study areas were relesed from grazing at the initiation of the study. It is possible that populations peaked during the first cycle before predators found these localized sources of abundant prey and became established in the area (the prairie had never supported high densities of Microtus during the previous 25 years; see below). Although quantitative data were not obtained, it was obvious from general observations that predators were much more prevalent during the second cycle in all areas. Least weasel captures in the live-traps during the second cycle were five times those of the first cycle. Domestic cats also appeared more commonly on the study areas during the second cycle.

It is also possible that late growth of vegetation, resulting in very little vole reproduction in spring 1975 (in contrast to high reproduction in spring 1972), delayed the start of the second cycle until late in the summer. However, this would not explain why the increase phase did not continue to a higher peak in 1976. Another factor which may have changed between the first and second cycles was the quality of forage on the study areas. Vegetative change over the course of this study was most pronounced in the alfalfa area (see Study Areas). The amount of alfalfa decreased after 1972 and the total percentage of cover consisting of dicots also decreased due to the invasion of grasses. In light of the work of Cole \& Batzli (In Press) on the food habits of $M$. ochrogaster, food quality, at least in the alfalfa area, may have been reduced during the second cycle.

Finally, the possible influence of interspecific competition must be considered. Since $M$. pennsylvanicus did not occur in the study region until 1973 and did not become abundant on the bluegrass and prairie area until 1975, interspecific competition could have affected $M$. ochrogaster population densities during the second cycle only. However, competition could not have been the sole mechanism responsible for reduced amplitudes of fluctuations, since $M$. pennsylvanicus did not become established in the alfalfa area until late 1976. 


\subsection{Synchrony}

Population fluctuations of $M$. ochrogaster during this study were essentially synchronous, especially in the alfalfa and bluegrass areas during the first cycle. The prairie population was slightly out of phase with the others. During 1975 of the second cycle, fluctuations in density in the alfalfa and bluegrass area populations were in close synchrony. In 1976, however, the bluegrass area population declined to low densities while the alfalfa area population increased again, reaching densities as high as those during the 1975 peak before the decline in autumn 1976.

The $M$. pennsylvanicus populations in the bluegrass and prairie areas did not fluctuate in close synchrony; the peak occurred four months earlier in the bluegrass than in the prairie. The $M$. pennsylvanicus population in the bluegrass area was completely out of phase with the sympatric population of $M$. ochrogaster.

\subsection{Population Cycles}

The population cycles observed in our study did not all support the Krebs \& Myers (1974) assumption that the increase phase occurs in the spring and that the population reaches a peak in autumn or early winter. While our first $M$. ochrogaster cycle began in early spring and peaked in late autumn-early winter, the second cycle started in late summer and had reached a peak by early autumn. The $M$. pennsylvanicus cycle in the bluegrass area started in late autumn and peaked in midsummer.

Krebs \& Myers (1974) and Gaines \& Rose (1976) concluded that length of the breeding season (especially variation in the time of the decreases in reproduction) is an important force driving microtine population cycles. Although we found that variation in length of the breeding season may have been partly responsible for differences in amplitude of fluctuation, it did not apper to drive the cycle. There was no indication that a longer breeding season was associated with the increase phase of any population of either species.

Reproductive intensity of $M$. ochrogaster in the alfalfa and bluegrass habitats was significantly greater during the increase phase of both cycles. We also found a negative correlation between the proportion of reproductive females and population density nine weeks earlier in these two populations. The prairie population of $M$. ochrogaster differed from the others in that reproduction was lower during the increase than during the decline phase of the cycle. Also, there was a positive correlation between population density and reproduction 9 weeks later. These ano- 
malies may have been the result of relatively small sample size and/or the absence of a clearly defined cycle in the prairie area. Data from the alfalfa and bluegrass habitats, however, indicate that changes in reproduction with changing population density may be a potential regulatory mechanism for $M$. ochrogaster.

There was a significant negative correlation between population density and reproduction 9 weeks later for $M$. pennsylvanicus in the prairie area. However, no such correlation was found for the bluegrass area population, and there was no significant difference in pregnancy rates between the increase and decline phases.

$\mathrm{Krebs}$ et al. (1968), Keller \& Krebs (1970), and Rose \& G ain e s (1978) indicated variation in reproductive intensity to be independent of phase of the cycle or trends in population density. However, they attempted correlations only between population density and level of reproduction during the same trapping period. In our study, such comparisons produced no significant or even consistently positive of negative correlations. Our results indicate a lag time of approximately 9 weeks in the effect of population density on reproductive activity. A lag time would be expected if a negative feedback mechanism is to generate periodic fluctuations. An instantaneous response of reproduction to changes in population density would tend to produce stability rather than fluctuations.

Negative feedback of population density effects on reproduction undoubtedly involve changes in the physiological status of the reproductive system. Owing to the response times necessary for the endocrine and reproductive organ systems to increase and decrease in activity, one would expect reproductive changes to lag behind changes in population density. A delay in the response of the reproductive system to changes in the social environment has been used previously to explain cyclic population fluctuations (Christian \& Davis, 1964; Christian, 1971b).

$\mathrm{M}$ a y (1976) indicated that in seasonal environments biological mechanisms with built-in time lags in the order of one year are involved in generating a 3-4 year population cycle. Since the average life span of the voles in our study was only $6-9$ weeks, it is difficult to envision density effects that could affect reproductive capacity of individuals present in the population a year later. A shorter lag time seems more appropriate for $M$. ochrogaster and $M$. pennsylvanicus.

A study of response times of the reproductive system to changes in environmental and social factors is necessary to determine if the 9-week lag observed in this study is physiologically valid.

In any event, there appears to be a distinct negative effect of 
population density upon reproduction at a later date. Such a lag effect has the potential of facilitating a population cycle.

Survival rates for adult $M$. ochrogaster were significantly higher during the increase than during the decline phases, expect for the alfalfa area population during the second cycle. Positive correlations between survival rates and population density $3-9$ weeks later indicate that increased survival may be a factor in generating a population increase. There does not, on the other hand, appear to be a feedback between density and survival which would initiate a decline phase. During the second cycle we did find a negative correlation between density and survival of $M$. ochrogaster 9 weeks later, however.

There was an indication (in the alfalfa area) that early juvenile survival of $M$. ochrogaster was related to phase of the cycle, population density and/or with density of adult males or females. G a in e s \& R o se (1976) concluded that early juvenile mortality may play a role in the demography of cycling $M$. ochrogaster; however, they did not identify the cause of changes in mortality. The mechanism responsible for differences in survival rates during the increase and decline phases does not appear to involve a population feedback mechanism. Hence, an external mechanism, e.g. predation, might be involved.

Survival rates of adult $M$. pennsylvanicus did not differ significantly between the increase and decline phases of the cycle. There was no significant correlation between population density and survival rates up to 9 weeks later.

However, survival of juveniles may be a factor involved in generation of population cycles in $M$. pennsylvanicus. Early juvenile survival and life expectancy following first capture as a juvenile were higher during the increase than during the decline phases in the bluegrass area. In addition, a negative correlation between density of adult females and early juvenile survival, as observed in the bluegrass, may play a role in population decreases. Therefore, it is possible that behavior of M. pennsylvanicus females toward young is a major factor involved in driving the population cycle of this species. Kre bs \& M yer s (1974) also indicated early juvenile survival of $M$. pennsylvanicus to be an important factor (although not the primary one) in determinig population growth of this species.

Weather appeared to influence the configuration and timing of the phases of the Microtus cycles observed in this study. The primary climatic extremes that can exert a significant impact on Microtus populations are heavy rains that flood underground and surface nests, extreme temperatures that may result in direct mortality and/or modify food availability, and drought which may affect food quality as well as 
water availability. Coincidences of climatic extremes and demographic changes suggest explanations for some of the changes in density during the course of the study.

During the spring of 1973 , heavy rains caused extensive flooding in all three study areas. This coincided with a decrease in survival and a sudden drop in population densities in late March-early April. However, a similar decrease in survival in spring 1976 was not preceded by heavy rains. Severe freezing rains and low temperatures in December 1973 may have produced high mortality during the winter 1973-74. Extreme flooding in all areas due to meltoff in February 1974, along with continued rains through June, presented unfavorable conditions for both survival and reproduction. Population densities of all three areas remained very low $(<10 /$ ha) during this period.

Low temperatures (and a resultant delay of approximately 1 month in plant phenology) immediately followed by extremely high temperatures in spring and early summer 1975, may have been unfavorable for normal spring and early summer reproduction. Population increases did not occur until late summer of 1975 . Temperatures well above normal during February and March 1976 induced an early growth response of grasses in the study areas. This may have been responsible for the early onset of reproduction by $M$. pennsylvanicus. Observations of population patterns and specific weather conditions over several cycles will be needed for a more precise estimation of the effects of weather on Microtus population fluctuations.

We did not measure predator populations on our study areas and thus do not have accurate data on predation over the course of the cycles. However, observations of high predation in an adjacent area (Cole \& B a tzli, 1978) in autumn 1975 suggest that predators may have been an important factor during the decline of $M$. ochrogaster populations in the alfalfa and bluegrass areas. A decrease in survival of adult $M$. pennsylvanacus also occurred at this time.

The sites employed in this study were located in a relatively small (14 ha) isolated area. Only smaller, discontinuous patches of suitable Microtus habitat (primarily roadsides) were present elsewhere in the general vicinity. When general population densities dropped to very low levels, there was no nearby population which could serve as a source of immigrants to maintain a modest transient population in our study areas. Population densities, therefore, were assumed to reflect phenomena characteristic of the populations in these specific study areas. Distinct demographic changes could not be attributed to immigration; results from other aspects of the study (Ve $r \mathrm{n}$ e $r$, 1978) suggested that little emigration occurs. 
The amplitude of fluctuation of prairie vole populations in the prairie was low and erratic (Fig. 1). Previous population data (annual autumn trapping) from this study area indicated periodic highs of at most $40 / \mathrm{ha}$ at 3-4 year intervals from 1944-1970 ( $\mathrm{K} \mathrm{e} \mathrm{n} \mathrm{d} \mathrm{e} \mathrm{i} \mathrm{g} \mathrm{h,} \mathrm{pers.} \mathrm{comm.).} \mathrm{The}$ - amplitudes of fluctuations observed in our study do not appear, therefore, to be unusually'low. Low food quality in the prairie might result in poor condition of the voles for long periods, such that reproduction and survival become too low to yield a high density peak phase It is also difficult to establish from our data that "cyclic " phenomena occurred in the prairie area; "phases " of the cycle are not distinct. Without data from the other two areas, it is doubtful that one would consider the population fluctuations observed in the prairie area during the five years of the current study to be cyclic in nature.

Average population densities and amplitudes of fluctuations of $M$. ochrogaster are lowest in the area most nearly resembling original prairie habitat of this species. Both average population densities and amplitudes of fluctuation were highest in the alfalfa, which was most unlike the original prairie habitat of $M$. ochrogaster. Population densities and amplitudes of fluctuation in the bluegrass area were intermediate between the other two habitats. The former habitat, while dominated by introduced plant species, is somewhat similar to the original habitat of $M$. ochrogaster in terms of vegetation type. It would appear, therefore, that the lower amplitude population fluctuations may be characteristic of the species. Higher population densities in prairie habitats than were observed in the prairie in this study have been recorded in Kansas by M a r tin $(80-100 /$ ha; 1956$)$ and $\mathrm{G}$ a in es \& $\mathrm{R}$ os e $(80-90 / \mathrm{ha} ; 1976)$, while Meserve found peak densities similar to ours in Nebraska ( $55 /$ ha; 1971). Comparisons of population densities in non-prairie habitats in these regions are not available, however.

The less natural habitats may present conditions to which social and demographic characters of $M$. ochrogaster are not adapted. Disruption of normal regulatory mechanisms becomes more pronounced, the more removed are the habitat characters from the original tall grass prairie, hence the increasing instability of $M$. ochrogaster populations in bluegrass and alfalfa habitats. Studies are under way to investigate social and demographic characteristics of $M$. ochrogaster that may relate to instability in more artificial, albeit more productive, habitats.

\section{CONCLUSIONS}

Habitat variation in the amplitude of fluctuation of $M$. ochrogaster populations appeared to be related directly to qualitative differences in 
food availability. Higher quality food sources resulted in longer breeding seasons which, in turn, resulted in higher peak densities. There was no evidence that qualitative differences in food availability or length of the breeding season drove the $M$. ochrogaster population cycle, however. Neither food availability nor length of the breeding season appeared to be responsible fo habitat variation in the amplitude of fluctuation of $M$. pennsylvanicus populations, or in generation of a population cycle.

A negative correlation (with a 9-week lag interval) between reproduction and population density appeared to be a major factor influencing a population decline in $M$. ochrogaster. A negative correlation between population density and juvenile survival was a secondary factor in the population decline of this species. A negative correlation between juvenile survival and female density appeared to be involved in the population decline of $M$. pennsylvanicus. There was no correlation between population density and reproduction in this latter species. i

Acknowledgements: The study was supported by NIH grant, HD 09328 to the senior author and by grants from the Granite City Steel Corporation, NIH Biomedical Program, and the University of Illinois Research Board. We thank the following individuals for assistance with the field work: John Edgington, Diane Carroll, Jim Hauffe, Pat Calbeck Harper, Martin Prather, and Susie Cole. Dr. G. O. Batzli and L. K. Schiller offered comments concerning the manuscript.

\section{REFERENCES}

1. Birney E. C., Grant W. E. \& Baird D. D., 1976: Importance of vegetative cover to cycles of Microtus populations. Ecology, 57: 1043-1051.

2. Boonstra R. \& Krebs C. J., 1978: Pitfall trapping of Microtus townsendii. J. Mammal., 59: 136-148.

3. Bujalska G., Andrzejewski R. \& Petrusewicz, K., 1968: Productivity investigation of an island population of Clethrionomys glareolus (Schreber, 1780). II. Natality. Acta theriol., 13: 412-425.

4. Burt W. H., 1940: Territorial behavior and populations of some small mammals in southern Michigan. Misc. Publ. Mus. Zool. Univ. Mich., 45: 1-58.

5. Chitty D., 1955: Adverse effects of population density upon viability of later generations. [In: "The numbers of man and animals«, Cragg J. B. \& Pirie N. W., eds.]. Oliver and Boyd: 57-67. Edinburgh.

6. Christian J. J., 1971a: Fighting, maturity, and population density in Microtus pennsylvanicus. J. Mammal., 52: 556-567.

7. Christian J. J., 1971b: Population density and reproductive efficiency. Biol. Reprod., 4: 248-294.

8. Christian J. J. \& Davis D. E., 1964: Endocrines, behavior and population. Science, 146: 1550-1560.

9. Cole F. R., 1977: Nutrition and population dynamics of the prairie vole. Microtus ochrogaster, in central Illinois. Ph. D. Thesis, Univ. Illinois, Urbana. $102 \mathrm{p}$. 
10. Cole F. R. \& Batzli G. O., 1978: The influence of supplemental feeding on a vole population. J. Mammal., 59: 809-819.

11. Cole F. R. \& Batzli G. O., In press: Nutrion and population dynamics of the prairie vole Microtus ochrogaster in central Illinois. J. Anim. Ecol.

12. Fitch H. S., 1957: Aspects of reproduction and development in the prairie vole (Microtus ochrogaster). Univ. Kans. Misc. Publ. Mus. Nat. Hist., 10: $129-161$.

13. Gaines M. S. \& $\mathrm{Krebs}$ C. J., 1971: Genetic changes in fluctuating vole populations. Evolution, 25: 702-723.

14. G a in es M. S. \& R o s e R. K., 1976: Population dynamics of Microtus ochrogaster in eastern Kansas. Ecology, 57: 1145-1161.

15. Getz L. L., 1960: A population study of the vole, Microtus pennsylvanicus. Am. Midl. Nat., 64: 392--405.

16. Getz L. L., 1961: Factors influencing the local distribution of Microtus and Synaptomys in southern Michigan. Ecology, 42: 110-119.

17. Getz L. L., 1970: Influence of vegetation on the local distributicn of the meadow vole in southern Wisconsin. Univ. Conn. Occas. Pap. Biol. Sci. Ser., 1: $213-241$.

18. Getz L. L., Cole F. R., \& G a te s D. L., 1978: Use of interstate roadsides as dispersal routes by Microtus pennsylvanicus. J. Mammal., 50: 208-212.

19. Golle y F. B., 1961: Interaction of natality, mortality and movement during one annual cycle in a Microtus population. Am. Midl. Nat., 66: 152-159.

20. Hamilton W. J., 1937: The biology of microtine cycles. J. Agr. Res., 54: $779-790$.

21. Hilborn R., Redfield J. A. \& Krebs C. J., 1976: On the reliability of enumeration for mark and recapture census of voles. Can. J. Zool., 54: 10191024.

22. Keller B. L. \& Krebs C. J., 1970: Microtus population biology. III. Reproductive changes in fluctuating populations of $M$. ochrogaster and $M$. pennsylvanicus in southern Indiana 1965-67. Ecol. Monogr., 40: 263-294.

23. $\mathrm{Krebs}$ C. J., 1964: The lemming cycle at Baker Lake, Northwest Territories, during 1959-62. Arctic Inst. N. Amer. Tech. Pap., 15. 104 p.

24. Krebs C. J., 1977: Competition between Microtus pennsylvanicus and Microtus ochrogaster. Am. Midl. Nat., 97: 42-49.

25. Krebs C. J., Keller B. L. \& Tamarin R. H., 1969: Microtus population biology: demographic changes in fluctuating populations of $M$. ochrogaster and M. pennsylvanicus in southern Indiana. Ecology, 50: 587-607.

26. Krebs C. J. \& M y ers J. H., 1974: Population cycles in small mammals. Adv. Ecol. Res., 8: 267-399.

27. Leslie P. H., Tener J. S., Vizos o M. \& Chit y H., 1955: The longevity and fertility of the Orkney vole, Microtus orcadensis, as observed in the laboratory. Proc. Zool. Soc. Lond., 125: 115-125.

28. M a rtin E. P., 1956: A population study of the prairie vole (Microtus ochrogaster) in northeastern Kansas. Univ. Kans. Publ. Mus. Nat. Hist., 8: $361-416$.

29. M a y R. M., 1976: Theoretical Ecology. W. B. Saunders Company, Philadelphia.

30. M e s e rve P. L., 1971: Population ecology of the prairie vole, Microtus ochrogaster, in the western mixed prairie of Nebraska. Am. Midl. Nat., 86: 417-433.

31. Rose R. K. \& Gaines M. S., 1978: The reproductive cycle of Microtus ochrogaster in eastern Kansas. Ecol. Mongr., 48: 21-42. 
32. Si e gel S., 1956: Nonparametric statistics for the behavioral sciences. McGrawHill: 1-31.2. New York.

33. Verner L., 1978: The significance of dispersal in fluctuating populations of Microtus ochrogaster and $M$. pennsylvanicus. Ph. D. thesis, Univ. Illinois, Urbana.

Accepted, April 10, 1979.

\section{APPENDIX I}

Formula used to estimate survival of voles from birth to trappable age (modified from B u ja Is k a et al., 1968)

First cycle, when 4-week trapping intervals were employed:

$$
B(t)=L * F(t-1) * I / 23
$$

where: $L=$ average litter size

$F(t-1)=$ number of females in advanced pregnancy in the previous trapping period $I=$ duration of trapping interval in days

and $23=$ average gestation period (days)

Survival was calculated as:

$$
\frac{J(t+1)}{B(t)}
$$

where: $J(t+1)=$ number of juveniles caught in trapping period $(t+1)$

Second cycle, when 3-week trapping intervals were employed, $B(t)$ was estimated as

$$
\alpha B(t)=L *(F(t-1)+F(t-2) / 2) * I / 23
$$

and survival was calculated as:

where $S=$ number of subadults.

$$
\frac{J(t+2)+S(t+2)}{B(t)}
$$


L. L. GETZ, L. VERNER, F. R. COLE, J. E. HOFMANiN i D. E. AVALOS

POROWNANIE WSKAŹNIKOW DEMOGRAFICZNYCH POPULACJI MICROTUS OCHROGASTER I M. PENNSYLVANICUS

\section{Streszczenie}

Porównano wskaźniki rozrodu, przeżywalności i liczebności dwóch cyklów populacyjnych u Microtus ochrogaster i jednego u M. pennsylvanicus. Badania prowadzono na uprawie lucerny, lące porośniętej trawa z rodzaju Poa oraz prerii wysokiej, we wschodnio-centralnym Illinois, w latach 1972-1976 (Tabela 1). Największe zagęszczenie populacji $M$. ochrogaster bylo na uprawie lucerny (240 i 110 osobników/ha), pośrednie na lące (125 i 60) a najniższe na prerii (37 i 12); $M$. pennsylvanicus wykazywał największe zagęszczenie na łące -49 osobnikow/ha, dalej na prerii - 31 i najmniejsze na uprawie lucerny - 11 zwierząt/ha.

Długość sezonu rozrodczego, sterowana dostępnościa pokarmu, jest odpowiedzialna za amplitudę wahań liczebności $M$. ochrogaster, lecz nie kieruje cyklami populacji (Tabela 3). Natomiast u $\boldsymbol{M}$. pennsylvanicus dostępność pokarmu nie wpływa na zakres fluktuacji liczebności lub cykl populacyjny.

Rozmnażanie się i przeżywanie młodych $M$. ochrogaster było większe w czasie fazy wzrostu populacji niż w czasie jej spadku (Tabela 4), natomiast u M. pennsylvanicus nie było tego rodzaju różnic (Tabela 5 ). U M. ochrogaster wystąpiła ujemna korelacja między rozmnażaniem a zagęszczeniem populacji (Tabela 6). Zmiany w rozmnażaniu są przypuszczalnie głównymi czynnikami odpowiedzialnymi za zapoczątkowanie spadku liczebności populacji $M$. ochrogaster; wzrost śmiertelności młodych miał drugorzędne znaczenie. Natomiast ten ostatni czynnik wydaje się być odpowiedzialny za spadek liczebności populacji $M$. pennsylvanicus. 